\title{
Assessment of Grassroots Empowerment Programs for Economic Development in Anambra State, Nigeria
}

\author{
Abasilim Angela Nneka ${ }^{1 *}$, Okhankhuele Omonigho Tonia ${ }^{1 \oplus}$
}

\author{
Department of Business \\ Administration, School of \\ Management Technology, Federal \\ University of Technology, Akure, \\ Nigeria \\ * Corresponding Author \\ (anabasilim@futa.edu.ng)
}

Received: 28 November, 2020

Revised: 24 February, 2021

Accepted: 6 May, 2021

Published: 10 June, 2021

How to cite this paper:

Abasilim, A. N; and Okhankhuele, O. T. (2021). Assessment of grassroots empowerment programs for economic development in Anambra state, Nigeria. Quest Journal of Management and Social Sciences, 3(1), 112-125.

Copyright (C) 2021 by authors and Quest Journal of Management and Social Sciences.

This work is licensed under a Creative Commons Attribution-Non Commercial-No Derivatives 4.0 International License.

https://creativecommons.org/

licenses/by-nc-nd/4.0/

\section{Abstract}

Background: The work is anchored on community development theory and decentralization process which emphasize both a holistic approach to development and transfer of power, functions, competencies, and means from the central government to the regional and local governments at the grassroots.

Objective: The study assessed the Anambra State Government's Grassroots Development Scheme for economic empowerment of community dwellers, in all the local governments of Anambra state, in Southeastern Nigeria. This was with the view to determine the extent of involvement of all the communities in the Government's Grassroots Development Scheme and the commitment of the people to the purpose for which the development scheme was initiated.

Method: The primary source of data was used for the study. The population was made up of all the indigenes of Anambra State. The total number of respondents selected for the study is 975. Data collected were analyzed using descriptive and inferential statistics.

Result: The result showed that all the communities were involved in the grassroots development scheme of the Government of Anambra state $(\chi 2=698.211, \mathrm{df}=4, \mathrm{p}=0.00)$. The research findings also showed that the communities were committed to the purpose for which the grassroots scheme was initiated $(\mathrm{r}=0.747, \mathrm{p}=0.00)$.

Conclusion: The study, therefore, concludes that all the communities in Anambra State were included in the grassroots development scheme of Anambra State and that the people of Anambra State were committed to the scheme as they embarked on and completed different development projects in the state.

Keywords: Anambra State; Community Development; Economic Empowerment; Grassroots Scheme.

Paper Type: Research paper

JEL Classification: O10, Y1 


\section{Introduction}

Development that is based on the cultural values of the people and takes a bottom-top approach holds the key to unlocking the development potentials and at the same time resolves the quagmire Nigeria has found itself since its independence in 1960 (Maduabum and Ighodalo, 2018). Continuing, the authors argued that the basis of sustainable development can be initiated by empowering the people through Community Based Organizations (CBOs), rather than seeking to replicate the Western prototype of development, to make the right choices and changes to improve living conditions. To realize this, the right caliber of leadership in charge of affairs is required to harness and utilize available resources for the growth and development of the grassroots.

Supporting the bottom-up approach, Stiles (1987) argued that an alternative to the "tree top" development, where the bureaucrats plan and peer down on their works from detached perches, is the bottom-up approach of grassroots development. In this approach, the people of a community plan their projects and manage financial and technical support themselves. This is obtainable in some parts of the Global North and South as noted by U.S. Congress (1988) that the people of a community get involved in the projects that concern them and the projects get materialized. The U.S Paper observed that 30 years of grassroots activities in the United States of America led to legal desegregation of public schools; in Nicaragua, land reforms came about as a result of mass participation in key decision making; in Zimbabwe, some women groups ensured that agrarian reforms in favor of women farmers; and in Mexico City, neighborhood groups formed health care centers and care homes to cater for the neglected and victims of natural disasters.

Maduabum and Ighodalo (2018) posited that one of the challenges that developing countries face is how to create the context of a stable political environment for socio-economic programs to be carried out. Also, there is the need to create a system of government that facilitates freedom of choice and liberty for the people to pursue their individual and corporate interests. Once these enabling environments are created, it becomes easy for the people to confront and resolve challenges facing them by using resources within their environment to create a condition of life where each stage is progressively better than the proceeding one.

The question that seeks an answer is how far the different organs of government in Nigeria have utilized the available resources to solve the problems of development and sustainability. Nigeria's socioeconomic infrastructures have been in a dilapidated state for some years even before the economy went into recession in 2015. Electricity supply and provision of other infrastructures have always been a problem in Nigeria. Anambra State, which is a state in the southeastern part of Nigeria, is not an exemption. The main source of water in Anambra State is through major rivers traversing the length of the State. Some of the communities in Anambra State do not have any river or stream and trek up to 10-20 kilometers to get to the nearest river or stream. In such communities, rainwater collected from rooftops into cisterns dug in the ground becomes their source of water for private and commercial purposes. In some cases, rich individuals and communities will drill a borehole for water supply. This is an expensive venture as sometimes to get water in some of the communities; one has to drill as deep as $700 \mathrm{ft}$, which can be as expensive as 2.3 - 2.5million Naira (6.05-6.6 thousand Dollars at the exchange rate of $\$ 380$ per Dollar in 2019) depending on the community and the distance from the nearest river or stream. As such, any solution to the problem of water and electricity supply is a welcomed development that will go a long way in solving both economic and social problems of the people especially the poor and underprivileged.

Apart from electricity and water problems, Anambra is also plagued by natural disasters like flooding and erosion menace. In the year 2012, the ravaging effects of floods in Nigeria became so drastic that it was seen as a national disaster. Among the 36 states of the Federation, Anambra State among other 34 states had a bitter experience of disaster caused by the flood. Chukwuemeka and Chukwujindu (2013) noted that bad governance neglected the construction of infrastructures in the State. This caused 
menacing natural disasters like flooding and erosion in some parts of the state leading to mass human migration and displacement in some communities. The authors argue that novel development policies for the state are of an immediate need to address the problems of governance and infrastructures. Infrastructure improvements, both physical and social, have lagged behind the growth in population. There are problems in environmental sanitation, erosion control, and the provision of social services. Some of the cities are characterized by inadequate and deteriorated road networks, unregulated building patterns, poor sanitation, uncontrolled street trading, mountains of garbage, and chaotic transport systems, creating congestion, noise pollution, and overcrowding. As such, Anambra State still has a long way to go in terms of meeting the demand and expectation of its citizenry in the areas of provision of social services and implementing people-oriented development policies.

Development programs in the areas of infrastructural facilities such as good roads/networks of roads, supply of good and adequate water, access roads in rural areas and hinterlands, provision of infrastructure for basic education of its children and youths, healthcare services, transportation services, rural electrification program and provision of information and communication technology(ICT) to the teaming and yearning people of Anambra state is inadequate. Thus, Chukwuemeka and Chukwujindu (2013) observed that the massive infrastructural requirements of the state have not been addressed; the mechanism for implementation and the resulting funding gap deteriorates the situation. Development strategies involving the people at the grassroots are a necessity in Anambra state.

In the face of the monumental needs for development, the Anambra State government embarked on development programs and strategies to solve some of the infrastructural problems encountered by the citizenry. One of such development schemes is the Grassroots Development Scheme. A grassroots scheme is a people-driven approach to community development. The Anambra State Government's community project covering the 179 autonomous towns in the 21 local government areas of the State is valued at about N7bn (about 18.4 million US dollars at \$380 in 2019). Divided into two phases, each community is entitled to the sum of N20 million for each phase of the program. The first phase of the scheme ended February/March 2017; with the second installment taking off almost immediately in March/April. Area-defined and citizen-centered, the program is an insightful venture of the State Government in community development (Afuba, 2017). Continuing, the author noted that the success of the present Anambra State grassroots scheme would restore community initiatives and participation that are so critical to the success of development ventures. The determination of the communities' need, the choice of the project, as well as its location and contractor, is the communities', with the latter selected from among the indigenes. The communities shoulder full responsibility for the projects, providing a safety meshnet for monitoring of construction and maintenance upon completion.

However, according to Dollery and Wallis (2001), good development strategy is not just about providing a range of local services but also about preserving the life and liberty of residents, creating space for democratic participation and civic dialogue, supporting market-led and ecologically sustainable local development, and encouraging outcomes that enhance the quality of life of citizens. It then becomes obvious that it is not just enough to lay claim to these development schemes but emphasis must be on carrying all the communities along and the commitment of the communities to the purpose for which the scheme was initiated must be investigated to determine the overall effectiveness of the scheme. This paper, therefore, is designed to investigate the extent of involvement of all the communities in the grassroots development scheme of the government of Anambra State and examine the extent of the commitment of the communities to the development purpose for which the scheme was initiated.

This is to determine the workability and sustainability of such development efforts of the government for the people at the grassroots for future purposes. As such, the following research questions were formulated; what is the extent of involvement of all the communities in the grassroots scheme of the government of Anambra State? What is the extent of the commitment of the communities to the development purpose for which the scheme was initiated? The broad objective is to investigate the outcome of the first phase of the Grassroots Scheme of the Government of Anambra State. The specific 
objectives are to; investigate the extent of involvement of all the communities in the grassroots scheme of Anambra State for development; examine the commitment of the communities to the development purpose for which the scheme was initiated.

The paper further identified the problem of the study; examined the empirical reviews of related literature; explained the theories on which the work was anchored; explained the methodology employed in the study; discussed the findings and the subsequent conclusions drawn from the findings and made appropriate recommendations.

\section{Review of Literature}

\section{Political Leadership and Grassroots Development}

Development as a concept refers to the ability of people to use their cultural values to change their environment and lives (Rudeback, 1997). And of course, it follows that the ability of a people to do this depends to a large extent on the type of leadership put in place by the people. Leadership is crucial to realizing any giant stride in pursuit of development, anywhere in the world. Nigeria is not an exception. There is a general belief all over the world that development is not the sole responsibility of government. In situations where government fails in its duties to promote development, community development efforts are encouraged to complement government efforts (Maduabum \& Ighodalo, 2018).

Development can only make sense to people when they are involved in the process of decision-making through the bottom-top approach. Popular participation is, therefore, crucial to development. Popular participation is seen here as the active involvement of people in a process of setting goals and making decisions not just the acceptability of results that satisfies the need to participate (Ake, 1994). The declining ability of the State in Nigeria to provide the necessities of life for the people makes it expedient for non-political grassroots leadership through CBOs and NGOs to complement efforts of the political leadership at various levels of government. In pursuance of this goal, popular participation of people in decision making and implementation could be crucial for grassroots sustainable development.

Several decades of development planning and implementations would appear to have failed to address the pressing concerns of Nigerians for improved welfare and well-being. Also, for many years, nonpolitical grassroots leadership appeared to have left their primeval setting for political appointments at the Federal and State levels thereby alienating the people of the grassroots. Such distancing of the mass populace from their leaders has robbed the development process of a vital support base and elements which encourage genuine development. The old pattern of top-bottom line to development has produced uneven allocation of wealth, power, exclusive access to essential resources, as well as an increased level of exploitation in society. This called for a people centered development paradigm that focuses on the basic needs of people. This paradigm shift is necessary if sustainable development is to be realized at the grassroots in the country. Buell (1987) in answering the question on how much development is a technical problem, to be resolved with better techniques and advisors, and how much it is a structural problem, rooted in economic and political realities, posited that improved techniques, machines, and infrastructure mean little without a corresponding improvement in the political status of the poor.

In fact, without the increased political power of the poor, technical solutions often aggravate existing inequalities. Going further, Buell (1987) argued that three decades of development dictated from above has proven that top-down strategies are unlikely to improve the lives of the rural poor. In other words, for any grassroots development scheme to be meaningful, it must involve full local control in the planning, implementation, management, and evaluation of a project. Defined in this way, participation in development schemes must imply control of all resources for development. Collaborating the above, Alozie (2011) noted that popular participation is an essential ingredient of community development, without which the efforts will not be sustainable. Kobani (2014) also concluded in her study that 
community development is crucially concerned with the issues of powerlessness and disadvantage, and as such should involve all members of society, and offer a practice that is part of a process of social transformation, for development to be meaningful and achievable.

\section{Concept of Participatory Community Development}

The lack of participation of recipients of development has been blamed for some of the disappointing performances of development efforts around the world (Waisbord, 2001; Willis, 2011). Participation means the active involvement of communities in need assessment, determination of priorities, planning, and execution of projects. It also refers to the contribution of potential beneficiaries to the realization of a project for their development (Mansuri and Rao, 2004). A major challenge of governance in the Nigerian context is the exclusion of citizens from participating in decision-making and nonimplementation of policies. As Nwankwo (2012) observed, one of the basic problems confronting Nigeria's political system today is the lack of effective participation of the people in matters affecting them. Participation is a factor of multiple variables comprising involvement in the decision-making process, implementation of made decisions, sharing in the benefits of made and implemented decisions, and monitoring the entire process.

Participation in community development encourages all members of the community regardless of their age or sex to participate in a process that allows them to express their needs and to decide their future with a view to their empowerment and sustainability. And the key factor in participation is the incorporation of local knowledge into projects' decision-making process.

Participation is fruitful for sustainable change as an active process by which beneficiaries or client groups influence the direction and execution of development projects to enhance their well-being in terms of income, personal growth, self-reliance, and other cherished values (Nwachukwu and Eze, 2007). Cahn and Camper (1998) view the process of participatory community development as a situation where the members of a community irrespective of sex or age actively participate in decision making and implementation processes. Participatory community development, according to him, motivates community members to take on the challenge of solving their local issues through participation rather than through the centralization of leadership.

The Christian Aids Nigeria (2017) concluded that active involvement of the community in the decision-making process develops a sense of ownership towards the project at hand. The sense of local ownership that develops from the participatory involvement in the decision-making and implementation process generates legitimacy that creates a strong social capital using the community to carry out the development projects. As such, Mamah (2011) concludes that a project implemented with the collaboration of the local community has always a better chance of credibility because it will be taken care of by the local people, hence, it increases the chances of sustainability.

Involvement in community development begets the commitment of both men and women. To achieve this commitment, inclusive participation of the people for the development policies and efforts are targeted. Participation can generally be split into two broad categories - a social movement perspective and a project-based or institutional perspective - (Bonye, Aasoglenang, and Owusu-Sekyere, 2013) both based on the underlying principle of integrating local contexts, through information from people and ensuring ordinary people are involved in decisions - making about their development. It, therefore, represents the voices of the different subgroups of a population and ensures the understanding of the government of the efficient way of working for different groups of people by involving the local communities in taking up these policies.

As such Afuba (2017) observed that the injections of the development scheme, based on community participation, have the potential of stimulating local economic activity and the diversification of the rural economy. It is the setting for increased productivity, higher employment opportunities, and rising incomes. At a time of national economic recession, the merit of these socio-economic interventions 
cannot be over-emphasized. The community development investment that will take cognizance of rural participation becomes the needed infusion for reflating the state's economy.

\section{Concept of Community Development}

Afuba (2017) noted that the United Nations defines community development as a process designed to create conditions of economic and social progress for the whole community with its active participation and the fullest possible reliance on the community's initiative. Consequently, the community development perspective places responsibility for the development of the community on the people. On the other hand, community development is anything that involves socio-economic changes which bring about the transformation of agrarian society to reach a common set of development goals based on the capabilities and needs of the people (Mama, 2011).

UNESCO (2005) defines community development as the process by which the efforts of the people are united with the government to improve the economic, social, and cultural conditions of communities. Community development is a veritable tool for fighting poverty and achieving economic prosperity at the grassroots level. The concept of community development embraced by most countries connotes a process through which rural poverty is alleviated by sustained increases in the productivity and incomes of low-income workers and households (Nwachukwu \& Eze, 2007). The provision of social services is reckoned upon in Nigeria as one of the most important features of community development. These essential services include education, health, roads, electricity, and potable water, among others.

The true success of any comprehensive, economic and social development program in Nigeria is primarily dependent on the extent to which it contributes to the well-being of the rural population. This is because the bulk of the country's population, resources particularly land, natural and mineral resources are in these areas. Much as the problem of rural poverty has been noted, even globally, there are yet controversies among policymakers on appropriate concepts of rural development and by extension, appropriate policies and strategies for the eradication of rural poverty. Mama (2011) identified three important aspects of community development to include, raising people's living standard, income and consumption levels, access to medical services, education, safe drinking water, etc. through relevant economic growth process; creating conditions conducive for the growth of people's self-esteem through the establishment of social institutions that promote human dignity and respect; increasing people's freedom by enlarging the range of the choices available to them by increasing varieties of consumer goods and services. It, then, goes to say that any effort by the government to make life better for the people or to empower the people economically, must address these areas highlighted above. The government scheme must be able to raise the standard of living of people; there must be easy access to medical services, education, safe drinking water, and the ability to access micro-credit for the people, especially the youth and women.

As such for any meaningful headway to be made in community development, it must involve the participation of the people for whom it was meant. This is because for Mamah (2011) community development seeks to empower individuals and groups of people by providing these groups with the skills they need to affect change in their community. It involves changing the relationship between ordinary people and people in a position of power so that everyone can take part in the issues that affect their lives. It seeks to empower individuals and groups in their community. It is a process of helping a community strengthen itself and develop towards its full potential.

\section{Theoretical Framework}

The work is anchored on community development theory and the decentralization process. Community development theory recognizes that maintaining roles, structures, and processes that are performing well is vital. The working community system has a dual structure. One side is designed for stability, regular performance, and predictability. The other side of the system is designed for evaluation and change. Community development theory accepts the proposition of classical conservatism that the 
cumulative opinions and rules of communal life are to be respected (Zaw, 2018). It indicates balanced respect for the potency of both tradition and social invention. Community development theory proposes that it is far more likely for the system to overweigh the conservative side. Community development theory advocates that in addition, the community system should allow equality of standing for citizen roles. It emphasizes a holistic approach that ensures that all factors are taken into account as a whole, interdependent for the benefit of all. This holistic approach must involve improved infrastructure, better health care, lower crime rates, and improved education and other advancements. Community development theory postulates that the capacity of community systems expands with the introduction and increasing use of democratic structuring. It suggests that as the level of complexity and uncertainty increases, democratic structuring becomes more suitable.

Community development theory postulates that increased capabilities and effectiveness of community systems bring substantial benefits to its members. There would be no purpose in working for the elaboration of a community system to improve abilities and performance unless there were benefits over cost to the people served. As such, community development theory is directed toward the improvement of community systems, not only toward individual improvement. Decentralization, likewise, is a process of sharing power between the different agencies of governments such that the central government transfers power, functions, competencies, and means to the regional and local governments at the grassroots (Bonye, Aasoglenang, and Owosu-Sekyere, 2013). Given the participatory nature of decentralization, the grassroots scheme of the Anambra government by engaging the participation of the community dwellers seeks to establish participatory democracy in which the citizens of a locality act directly in the process of both local governance and economic development. The central theme and driving force of the scheme were that of decentralization within which two objectives directly are to create opportunity for the majority of rural dwellers, in the villages and towns to take part in collective decision making and gain access to political authority, and in so doing promote local economic development with the involvement of the people as a special preoccupation to improve living conditions in the state.

In conception and execution, the Anambra State intervention in community development for economic empowerment is a departure from the government-dominated approach that tends to distort the policy and, indeed, reduces the local populations to spectators. The present Anambra State version has restored community initiative and participation that is critical to the success of the venture. This is to say that the determination of the community's need, the choice of the project, as well as its location and contractor is selected from the community itself. The communities assume full ownership of the projects, providing a safety net for monitoring of construction and maintenance upon completion (Afuba, 2017). The author, therefore, concludes that the injections of the development scheme have the potential of stimulating local economic activity and the diversification of the rural economy. It is the setting for increased productivity, higher employment opportunities, and rising incomes. At a time of national economic recession, the merit of these socio-economic interventions cannot be overemphasized. The community development investment becomes the needed infusion for reflating the state's economy and empowering the common people, especially the youth and women.

From the examination of relevant literature, it is evident that a lot of work has been done on communityinvolved development, but the argument of this paper is to investigate the success of governmentled grassroots development scheme, from the people for whom the schemes are meant, being both beneficiaries and participants of the development scheme using Anambra State as a point of reference.

\section{Research Hypotheses}

The following hypotheses were tested;

$\mathrm{H}_{0}$ : All the communities were not involved in grassroots development scheme; and

$\mathrm{H}_{1}$ : The people of the communities were not committed to the development purpose for which the scheme was initiated. 


\section{Research Method}

Anambra State is located in the Southeastern part of Nigeria (Figure 1). It is made up of 21 Local Government Areas/Councils and 179 towns/communities. The 2006 Population Census put the population of Anambra State at 4,177,828 and the population estimate for 2016 put it at 5,527,800 (Nigeria Population Commission, 2006). Anambrarians, as the indigenes are addressed, are very industrious, and most of the industrial base of the state is private sector driven, spanning from agroallied, automobile, and manufacturing situated mostly in the Nnewi industrial belt. Onitsha is the main commercial city, and the Onitsha market is reputed to be the biggest in West Africa.

\section{Figure 1: Map of Nigeria and Map of Anambra State}

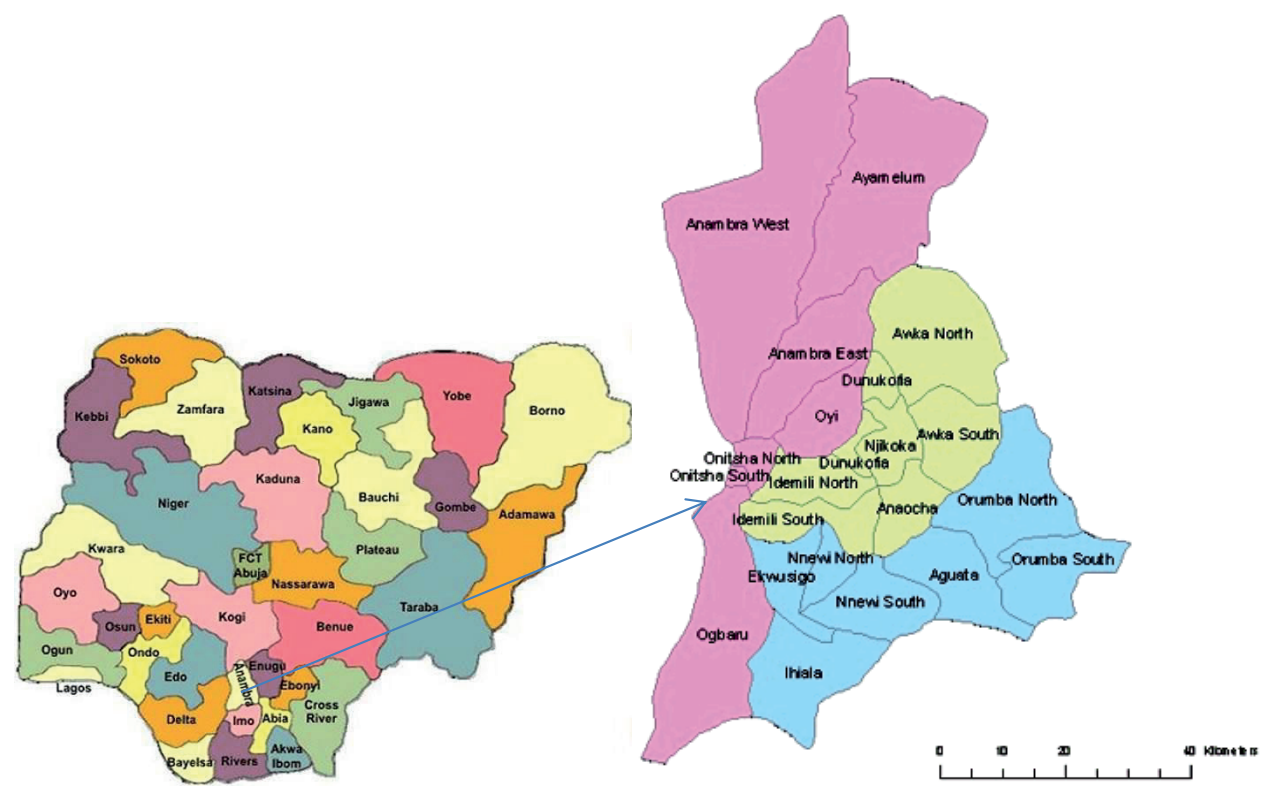

Source: google.com 2019

The primary source of data collection was used for the study. The data were collected through the administration of the questionnaire. The population of the study is the citizens of the state who are twenty-one years of age or older who have participated in the execution of the schemes and who are still actively involved in the administration of the schemes. The towns in the local government areas where the development schemes are or were sited are purposively selected. Then as many as possible of citizens of these communities who meet the criteria earlier stated were randomly selected. In total, 975 citizens of the state were selected and they formed the sample size of the study. A structured questionnaire was administered to the 975 respondents on how they were involved in the schemes and how they were engaged or committed to the schemes. This was done to ensure that respondents selected have the capability and knowledge to respond to the questions. Data collected were analyzed using descriptive statistics of percentages, frequency distribution, and bar charts. Inferential statistics used are Chi-Square Tests, Correlation analysis, and Cross tabulation.

The study examined both holistic approaches to development by investigating whether all the communities were included in the development agenda and analyzed whether there is a transfer of power and other competencies from the central government to the grassroots and the success recorded in doing this. This is an improvement to the previous studies conducted in this area of study. 


\section{Decision Parameter}

The decision rule used throughout this analysis is to reject the null hypothesis (Ho) and accept the alternative $(\mathrm{Ha})$ if the resulting $\mathrm{p}$-value is less than the 0.05 level of significance $(\mathrm{p}<0.05)$.

\section{Data Analysis and Result}

Distribution of Respondents by Socio-Demographic and Economic Characteristics

Table 1: Distribution of Respondents by Socio-Demographic and Economic Characteristics

\begin{tabular}{|c|c|c|c|}
\hline \multicolumn{2}{|c|}{ Socio-Demographic and Economic Characteristics } & $\begin{array}{c}\text { Distribution } \\
\text { Frequency } n=719\end{array}$ & $\begin{array}{c}\text { Percentage } \\
(\%)=100\end{array}$ \\
\hline \multirow[t]{3}{*}{ Gender } & Female & 234 & 32.5 \\
\hline & Male & 485 & 67.5 \\
\hline & Total & 719 & 100.0 \\
\hline \multirow[t]{7}{*}{ Age } & $21-30$ & 103 & 14.3 \\
\hline & $31-40$ & 210 & 29.2 \\
\hline & $41-50$ & 219 & 30.5 \\
\hline & $51-60$ & 51 & 7.1 \\
\hline & $61-70$ & 126 & 17.5 \\
\hline & $70 \&$ Above & 10 & 1.4 \\
\hline & Total & 719 & 100.0 \\
\hline \multirow[t]{22}{*}{ LGA } & Aguata & 38 & 5.3 \\
\hline & Anambra East & 39 & 5.4 \\
\hline & Anambra West & 34 & 4.7 \\
\hline & Anaocha & 26 & 3.6 \\
\hline & Awka north & 40 & 5.6 \\
\hline & Awka south & 41 & 5.7 \\
\hline & Ayamelum & 27 & 3.8 \\
\hline & Dunukofia & 25 & 3.4 \\
\hline & Ekwusigo & 41 & 5.7 \\
\hline & Idemili north & 39 & 5.4 \\
\hline & Idemili south & 40 & 5.5 \\
\hline & Ihiala & 42 & 5.8 \\
\hline & Njikoka & 26 & 3.6 \\
\hline & Nnewi north & 11 & 1.5 \\
\hline & Nnewi South & 44 & 6.1 \\
\hline & Ogbaru & 44 & 6.1 \\
\hline & Onitsha north & 18 & 2.5 \\
\hline & Onitsha south & 19 & 2.6 \\
\hline & Orumba north & 44 & 6.1 \\
\hline & Orumba south & 41 & 5.7 \\
\hline & Oyi & 40 & 5.6 \\
\hline & Total & 719 & 100.0 \\
\hline
\end{tabular}




\section{Occupation}

Artisan (trader, carpenter,

bricklayer, cleaner, etc.)

Civil servant (teacher, govt.

worker, clerk, etc.)

Farmer

Not employed yet

Religious leader

Student

Town union executive

Total

Source: Field Survey 2019

Nine hundred and seventy-five (975) copies of the questionnaire were distributed to selected respondents in this study. However, out of the 975 copies of the questionnaire administered to the sampled population (respondents), 719 questionnaires (Seven hundred and nineteen) representing $73.7 \%$ of the total questionnaires were found usable for statistical analysis (Table 1). The information in Table 1 showed that $32.5 \%$ of the respondents were females while $67.5 \%$ were males. The majority of the respondents were within the age group of 31-50 years which represents $59.7 \%$. As presented in Table 1, most of the respondents were artisans and low-level civil servants (59.7\%).

\section{The Extent of the Involvement of all the Communities in the Grassroots Scheme of N20m for Development}

The objective in this section was to determine whether all the communities were involved in the grassroots scheme as claimed by the state government. As such two sets of questions were asked to determine the extent of involvement. All the questions were measured on a five-point Likert scale from 'a very large extent' to 'not at all. The extent or percentage of the involvement of all the communities in the grassroots scheme of $\$ 20 \mathrm{~m}$ for development is 86.787 . The statistical significance of this result was determined using the Pearson Chi-square coefficient. The null hypothesis is that all the communities were not involved in the grassroots development scheme. This assumption was tested at a 0.05 level of significance and it was rejected because the p-value was less than $0.05(\chi 2=698.211$, df $=4, \mathrm{p}=0.00)$. The alternative was accepted which states that all the communities were involved in the grassroots development scheme (Tables 2 and 3).

Table 2: The Extent of the Involvement of all the Communities in the Grassroots Scheme of \#20m for Development

\begin{tabular}{|c|c|c|c|c|c|c|c|}
\hline \multirow{2}{*}{\multicolumn{2}{|c|}{ Name of Communities in Anambra State }} & \multicolumn{6}{|c|}{$\begin{array}{l}\text { The extent to which the Anambra state government's } \\
\text { donation of } \# 20 \mathrm{~m} \text { for developmental projects include } \\
\text { each community in the state }\end{array}$} \\
\hline & & \multirow{3}{*}{$\begin{array}{l}\text { Not } \\
\text { at all } \\
\mathrm{f}\end{array}$} & \multirow{3}{*}{$\begin{array}{l}\text { Not to } \\
\text { a large } \\
\text { extent }\end{array}$} & \multirow{3}{*}{$\begin{array}{l}\text { On an } \\
\text { average } \\
\text { extent } \\
\mathrm{f}\end{array}$} & \multirow{3}{*}{$\begin{array}{c}\text { To a } \\
\text { large } \\
\text { extent }\end{array}$} & \multirow{3}{*}{$\begin{array}{l}\text { To a very } \\
\text { large } \\
\text { extent } \\
\mathrm{f}\end{array}$} & \multirow{3}{*}{$\begin{array}{c}\text { Total } \\
\mathbf{f}\end{array}$} \\
\hline & & & & & & & \\
\hline & & & & & & & \\
\hline \multirow[t]{4}{*}{ Name of Community } & Abacha & 0 & 1 & 4 & 6 & 7 & 18 \\
\hline & Abagana & 0 & 0 & 2 & 8 & 5 & 15 \\
\hline & Achalla & 0 & 0 & 3 & 10 & 7 & 20 \\
\hline & Achina & 0 & 0 & 1 & 11 & 5 & 17 \\
\hline
\end{tabular}




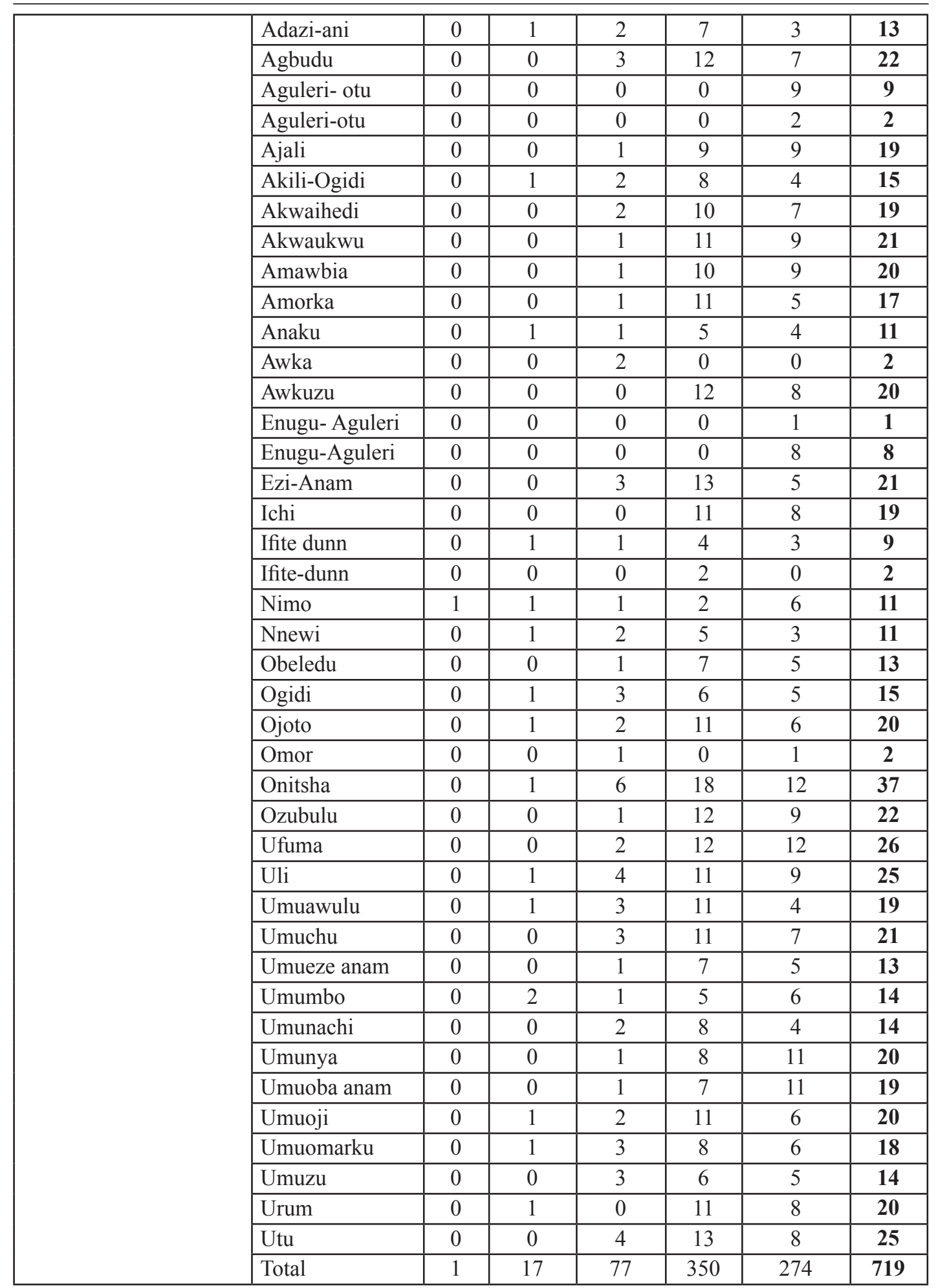


Table 3: Chi-Square Tests on the Extent of the Involvement of all the Communities in the Grassroots Scheme of \#20m for Development

\begin{tabular}{|c|c|c|c|c|c|c|}
\hline & Observed N & Expected N & Residual & Chi-Square & df & p \\
\hline Not at all & 1 & 143.8 & -142.8 & \multirow{5}{*}{698.211} & \multirow{5}{*}{4} & \multirow{5}{*}{0.00} \\
\hline Not to a large extent & 17 & 143.8 & -126.8 & & & \\
\hline On an average extent & 77 & 143.8 & $-6 \mathrm{~T}$ & & & \\
\hline To a large extent & 350 & 143.8 & 206.2 & & & \\
\hline To a very large extent & 274 & 143.8 & 130.2 & & & \\
\hline Total & 719 & & & & & \\
\hline
\end{tabular}

Source: Field Survey 2019

\section{The Commitment of the Communities to the Development Purpose for which the Scheme was Initiated}

The objective in this section was to determine whether all the communities were committed to the development purpose for which the scheme was initiated by the state government. Two sets of questions were asked to determine the extent of the commitment of the community leaders to the scheme and also examine the different projects embarked upon and completed by the communities. All the questions were measured on a five-point Likert scale from 'a very large extent' to 'not at all.' Using Spearman rho's correlation coefficient, it was observed that there is a correlation between government community development initiatives and the commitment of the communities to stay the course on their development. This was revealed by the extent to which the community dwellers used the money for the development purpose for which it was given. The analysis showed a high and significant correlation between the Anambra State government's donation of $\$ 20 \mathrm{~m}$ for development projects for all communities in the state and the commitment of the communities to the scheme initiated. $(\mathrm{r}=0.747$, $\mathrm{p}=0.00$ ). The null hypothesis that the communities were not committed to the purpose for which the scheme was initiated was tested at a 0.05 level of significance and it was rejected because the p-value was less than $0.05(\mathrm{r}=0.747, \mathrm{p}=0.00)$. The alternative was accepted which states that communities were committed to the development purpose for which the scheme was initiated (Table 4).

Table 4: The Degree of the Commitment of the Communities to the Purpose for which the Scheme was Initiated

\begin{tabular}{|l|l|l|}
\hline & & $\begin{array}{l}\text { The extent to which the Anambra State } \\
\text { government's donation of \#20m for } \\
\text { developmental projects include each } \\
\text { community in the state }\end{array}$ \\
\hline \multirow{2}{*}{$\begin{array}{l}\text { To what extent have the community } \\
\text { leaders used the money for the } \\
\text { purpose for which it was given }\end{array}$} & $\begin{array}{l}\text { Correlation } \\
\text { Coefficient }\end{array}$ & $0.747 *$ \\
\cline { 2 - 3 } & $\mathrm{p}$ & \multicolumn{1}{|c|}{0} \\
\cline { 2 - 3 } & $\mathrm{N}$ & 719 \\
\hline
\end{tabular}

Source: Field Survey 2019

\section{Discussion}

The findings are in agreement with the community development theory that advocates that the community system should allow equality of standing for citizen roles which emphasize a holistic approach that ensures that all factors are taken into account as a whole, interdependent for the benefit of all. This holistic approach must involve improved infrastructure, better health care, lower crime rates, and improved education and other advancements. Community development theory postulates 
that capacity of community systems will expand with the introduction and increasing use of democratic structuring. It suggests that as the level of complexity and uncertainty increases, democratic structuring becomes more suitable. In other words, to achieve development at the grassroots, the people at the grassroots must be involved in development schemes at both planning and execution.

The research findings also agree with the studies of Buell (1987), Alozie (2011), and Kobani (2014) that posited that for any grassroots development scheme to be meaningful and successful, it must involve full local control in the planning, implementation, management, and evaluation of a project; that participation in development schemes must imply control of all resources for development; that popular participation is an essential ingredient of community development, without which the efforts will not be sustainable; and, that community development is crucially concerned with the issues of powerlessness and disadvantage, and as such it should involve all members of society and offers a practice that is part of a process of social change for development to be meaningful and achievable.

The findings are also in agreement with the summation of Afuba (2017) that when the determination of the community's need, the choice of the project, as well as its location and contractor, is the community's - with the latter selected from one of their own, the communities assume full ownership of the projects, providing a safety net for monitoring of construction and maintenance upon completion. This is noted by the successful completion of different types of developmental projects by the communities in Anambra State. The findings are also in agreement with Bonye et al (2013) that when power is decentralized among the different levels of government, success is more likely to be achieved.

\section{Conclusion and Recommendations}

Based on the findings of the study, the following conclusions were drawn. The result of the study showed that all the communities benefitted from the grassroots development scheme of the Government of Anambra State. The null hypothesis is that all the communities were not covered in the grassroots development scheme. This assumption was tested at a 0.05 level of significance and it was rejected because the $\mathrm{p}$-value was less than $0.05(\chi 2=698.211, \mathrm{df}=4, \mathrm{p}=0.00)$. The research findings also showed that the communities were committed to the purpose for which the grassroots scheme was initiated by the Anambra State government. The null hypothesis that the communities were not committed to the purpose for which the scheme was initiated was tested at 0.05 level of significance and was rejected because the $\mathrm{p}$-value was less than $0.05(\mathrm{r}=0.747, \mathrm{p}=0.00)$. The study, therefore, concludes that all the communities in Anambra State were included in the grassroots development scheme of Anambra State and that the people of Anambra State were committed to the scheme as they embarked on and completed different developmental projects in the state.

The study recommends that the government and its agencies should come up with more of such schemes to help in empowering the people economically. This will be a way of boosting the economy and diversifying economic activities thereby laying less emphasis on oil as a source of revenue. Of course, these efforts by the government to make life better for the people should be duly monitored both by the people for whom they are meant and also by the government and government agencies responsible for them. This is to ensure accountability and equitable distribution of common resources for the common good.

The study concentrated only on the beneficiaries of the development scheme as provided by the Anambra State government. The study did not probe the agencies of the state government to investigate the level of compliance and participation of the communities in the government's initiatives. The study is also limited to only one state, other states in Nigeria can also be investigated to determine the commitment of the government to grassroots development. 


\section{Conflict of Interest}

The authors declared that there is no conflict of interest while preparing this paper.

\section{References}

Afuba, I. (2017). Anambra's innovative community development scheme. The Sun News. January 26, 2018. Sunnewsonline.com./2017/02/20/Home/Opinion/Anambra's innovative community development scheme.

Ake, C. (1994). Democratization of disempowerment in Africa, center for Africa social sciences. Accessional monograph, (1).

Alozie, K. (2011). Cultural practices affecting the well - being of women from a community development perspective. Unpublished Ph.D Dissertation, University of Port Harcourt, Choba - Port Harcourt.

Bonye, S., Thaddeus, A., and Ebenezer A., Owusu-Sekyere. (2013). Community development in Ghana: Theory and practice. European Scientific Journal, 9(17), 79-101.

Buell, R. (1987). Grassroots development: A question of empowerment. Cultural Survival Quarterly, 11(1), 34-37.

Cahn, E. S. and Jean C. C. (1968). Citizen participation in urban development. (Vol. 1). Center for Community Affairs, NTL, Institute for Applied Behavioral Science, Washington, DC, pp. 211-224.

Christian Aid Nigeria. (2017). Enhancing community participation and government responsiveness: Approaches to achieving community development. Country Office Nigeria.

Chukwuemeka, E., \& Chukwujindu, C. E. (2013). The effect of Anambra integrated development strategy (ANIDS) on Nigeria sustainable development: An appraisal (2006-2011). European Journal of Business and Social Sciences, 2(9), 95-113.

Dollery, B., \& Wallis, J. L. (2001). The political economy of local government. Edward Elgar Publishing.

Kobani, D. (2014). Grassroots Perception and Participation in Community Development Programs in Etche Local Government Area. Development, 4(12).

Maduabum, C., \& Ighodalo, A. Non Political Grassroots Leadership and Sustainable Development in Nigeria: An Analysis of Challenges and Policy Proposals. European Scientific Journal.

Mamah, C. I. (2015). Participation of women in community development in Nigeria: A case study of Igbo Eze south local government area, Enugu State (Doctoral dissertation).

Mansuri, G., \& Rao, V. (2004). Community-based and-driven development: A critical review. The World Bank Research Observer, 19(1), 1-39.

National Population Commission. (2010). Population and housing census of the Federal Republic of Nigeria 2006.

Nwachukwu, I. N., \& Ezeh, C. I. (2007). Impact of selected rural development programmes on poverty alleviation in Ikwuano LGA, Abia State, Nigeria. African journal of food, agriculture, nutrition and development, $7(5)$.

Nwankwo, O. B. C. (2012). The challenges of political education in contemporary Nigeria: Re-thinking mission and re-planning strategies. Education Research Journal, 2(12), 392-399.

Rudebeck, L. (1997). 'To seek happiness': development in a West African village in the Era of democratisation. Review of African Political Economy, 24(71), 75-86.

Stiles, D. (1987). Classical versus grassroots development. Cultural Survival.

UNESCO. (2005). World report towards knowledge societies. Paris: UNESCO.

U.S. Congress, Office of Technology Assessment, (1988). Grassroots development: The African

Development Foundation, OTA-F-378 (Washington, DC: U.S. Government Printing

Office).

Waisbord, S. (2020). Family tree of theories, methodologies, and strategies in development communication. Handbook of communication for development and social change, 93-132.

Willis, K. (2011). Theories and practices of development. [e-book] 2nd ed. London: Routledge.

Zaw, N. T. (2018). Community development theory: Basic introduction on how community development theories develop and work". Available at: www.academia.edu/2564568/community Development 